\title{
Opportunities and Challenges Faced by Xinjiang Enterprises in the Marketing under the Strategy Background of One Belt One Road
}

\author{
Lei Jia \\ School of business, Xinjiang Vocational University, Urumqi Xinjiang, 830013, China
}

Keywords: Xinjiang agricultural products trade enterprises, One belt One road strategy, Market structure, Agricultural products, SWOT.

\begin{abstract}
The Xinjiang region is the core strategy of the new Silk Road, as the country continues to advance "One belt One road" strategy, the Xinjiang regional advantages, resources and local policies are also increasingly prominent. In this paper, Xinjiang agricultural enterprises marketing structure of its international market structure as a starting point, the empirical analysis of the agricultural production enterprises in the province's regional competitiveness, based on SWOT Xinjiang to discuss agricultural trade enterprises in the marketing process the strengths, weaknesses, opportunities and challenges.
\end{abstract}

\section{Introduction}

"One belt One road" strategy refers to generation is the "21st century Silk Road Economic Belt", which is China's economic development and transformation of the established comprehensive, open a new pattern. As the future of the world's longest span economic corridor, the development prospects of the "New Silk Road Economic Belt" is quite broad optimism on this corridor contains the country's largest provinces - Xinjiang. Xinjiang in the foundation and supporting facilities construction in recent years has been quite perfect, resource development and utilization, trade and investment have also established a very important position in the country's western region, and gradually began to the five Central Asian foreign expansion, in order to greater foreign economic objectives. Therefore, the systematic developments of new Silk Road economic belt this long-term project, Xinjiang province, all walks of life companies will be a major opportunity and challenge.

\section{The basic structure and economic characteristics of agricultural trade of Xinjiang}

\section{The status of Xinjiang agricultural trade enterprises in domestic market.}

Under the correct guidance "One belt One road" strategy, Xinjiang agricultural trade enterprises in the overall development direction of good performance, especially in recent years has occupied an important seat in China agricultural trade market. Take 2002, for example, the total import and export of all agricultural enterprises accounted for Xinjiang province of China to $1.85 \%$ of agricultural trade, and this data in 2014 dropped to $0.66 \%$, of which imports rose from 12 years ago, $0.22 \%$ to $0.34 \%$, while the proportion of exports increased from $2.18 \%$ to $1.20 \%$, so in absolute volume terms, total trade show in Xinjiang fluctuations in the steady rise of the situation there, from 2002415803500 US dollar increased to $\$ 1,227,844,300$ in 2014 , the growth rate reached $178.42 \%$. In addition, Xinjiang from 2010 to 2014 for five consecutive years to achieve a total import and export more than 1 billion US dollars, showing a strong upward momentum in enterprises in the province of foreign business development process, and maintained a large trade surplus, very good the response to the "One belt One road" to the call, played a central role in the economic development of the new Silk Road economic belt, is China's agricultural foreign trade volume made a great contribution.

International market pattern of Xinjiang agricultural products trade enterprises.

Speaking foreign trade volume would have to talk about the overall pattern of Xinjiang agricultural trade enterprises in the international market, from the point of view of the situation intercontinental marketing, Asia, Europe and Africa has become a major export market for agricultural products in Xinjiang, which in Asia, the largest proportion, accounting for 68\% of the overall proportion. The proportion of exports from the three years of 2012 - 2014, the proportion of 
total exports of enterprises in the province of Xinjiang five Central Asian countries were 68.32\%, 69.11\% and 67.23\%, and therefore the most stable in Asia or Xinjiang agricultural products and export to international markets. Especially in the implementation of the 2014 "One belt One road" policy, Xinjiang Agricultural Import share in Asia almost 70\% breakthrough, showing China's new Silk Road Economic Belt absolute monopoly in the Asian markets for agricultural products range.

\section{Fate and the main source of agricultural enterprises in Xinjiang.}

Mentioned above, the company's products Xinjiang Agricultural trade is the main export market for the five countries of Central Asia, in fact, the EU and Russia also occupies a considerable share (respectively 13.29\% and 11.50\%) came in Kazakhstan (15.22\%) and Kyrgyzstan (6.53\%) between.

The sources of imports, imports of agricultural products market in Xinjiang including Uzbekistan, Kazakhstan, Australia and Pakistan, respectively accounted for 32.05\%, 21.60\%, 6.12\% and 5.20\%, together accounted for total imports of agricultural enterprises in Xinjiang 64.97\%.

Overall, after "One belt One road" strategy, Xinjiang agricultural enterprise marketing environment has been further opening up trade in agricultural products through a number of enterprises in the province to achieve the economic, cultural and even political level between local exchanges and intermediation. This will not only promote agricultural enterprises in Xinjiang province in the interests of business and marketing environment, but also steadily promote the development trend of the Xinjiang regional economy, it can be said based on Xinjiang's "One belt One road" strategy really played an active national political strategy the local economy, "with a little face" effect, also realized in Xinjiang province and healthy development of agricultural trade enterprises to actively explore new Silk Road economic belt core strategy "to point" the purpose [1].

\section{Opportunities and Challenges in Xinjiang agricultural enterprises in marketing faces}

SWOT model of management is the most common method of analysis, it can be a competitive advantage (Strength), disadvantages (Weakness), opportunity (Opportunity) and challenges (Threat) one by one in the development of a clear corporate strategy properly and deficiencies . Xinjiang agricultural enterprises within the meaning of the opportunities that the market opportunity come from the positive economic and environmental impact of policies, such as "One belt One road", which will affect the future long-term development. The challenge comes from external threats, such as the Asian country outside China or the competition more and more stringent management and control of the international agricultural sector. In the SWOT model, which can be be a good depth analysis.

\section{Competitive advantage of Xinjiang agricultural products enterprises.}

First, Xinjiang is an important segment corridor "New Silk Road Economic Belt", which runs through Central Asia and western regions of China, geographical advantages are obvious. This is China's foreign trade development is crucial, it opens up a natural trade route Xinjiang agricultural enterprises. From the details view, Xinjiang province in 2014 agribusiness agricultural export partners focused on Central Asia, Kazakhstan, Kyrgyzstan and Russia and other European countries. In addition, Xinjiang China has the largest foreign trade port, which include 17 first-class ports and 11 second-class ports, which together formed the country "East and west, west to east," the forefront of economic and trade, is new Silk Road economic belt of the best economic growth.

Climate, Xinjiang abundant sunshine and temperature difference significantly, year-round from 2500 to 3500 long enough light and geothermal resources for crop growth and accumulated enough nutrients and photosynthesis factors, vegetables and fruit crops in Xinjiang in the cultivation stage is an inherent advantage.

\section{Competitive weakness of Xinjiang agricultural products enterprises.}

Competitive disadvantages and advantages of Xinjiang agricultural products as obvious, it is mainly reflected in the strategic aspects of the industry structure and competitive business development, also includes the related auxiliary industries and government intervention and policies are introduced. Although the 2014 "One belt One road" strategy has published and spread gradually implemented, but in fact it still exists in many enterprises in the province inherent disadvantage. 


\section{1) Brand awareness weak and no leading enterprises}

Although many regional characteristics of agricultural products in Xinjiang province, but did not establish domestically and globally competitive brands, such as Khotan Junzao, Turpan grapes, etc. although it is well known, but brand awareness is still weak efficiency, which shows Xinjiang province enterprises in brand building is the lack of enterprise development environment, there is no agglomeration effect formation of the brand. From a technical point of view, Xinjiang province of large-scale agricultural enterprises and export enterprises finishing less, and low grade, can not drive the overall economic development in the province, the added value is quite low, exports of agricultural products need to effectively improve the degree of processing, its export growth has yet to benefit.

\section{2) Low level trade logistics}

Competitive disadvantages and advantages of Xinjiang agricultural products as obvious, it is mainly reflected in the strategic aspects of the industry structure and competitive business development, also include the related auxiliary industries and government intervention and policies are introduced. Although the 2014 "One belt One road" strategy has published and spread gradually implemented, but in fact it still exists in many enterprises in the province inherent disadvantage.

Brand awareness weak, no leading enterprises

Although many regional characteristics of agricultural products in Xinjiang province, but did not establish domestically and globally competitive brands, such as Hotan Junzao, Turpan grapes, etc. although it is well known, but brand awareness is still weak efficiency, which shows Xinjiang province enterprises in brand building is the lack of enterprise development environment, there is no agglomeration effect formation of the brand. From a technical point of view, Xinjiang province of large-scale agricultural enterprises and export enterprises finishing less, and low grade, can not drive the overall economic development in the province, the added value is quite low, exports of agricultural products need to effectively improve the degree of processing, its export growth has yet to benefit.

Low level trade logistics

As the "One belt One road" strategy policy, so characteristic of agricultural trade services are further strengthened, relatively speaking services and logistics industry development in Xinjiang is lagging behind, which is due to the imperfections of its logistics infrastructure caused by the . This includes aspects of the service system, information network, logistics chain, and service personnel can not fully meet the international development trend. Immaturity of these factors have seriously affected the export of transport, storage and distribution of value-added service quality of agricultural products, development of Xinjiang province on marketing effectiveness is hampered agricultural enterprises [2].

\section{Business opportunity of A Xinjiang agricultural product in marketing activities}

"One belt One road" strategy for the development of agricultural enterprises in the province of Xinjiang has brought great opportunities, Take A agricultural enterprises, for example, the company will for the domestic and international marketing activities clear their own action plan, deepening reform, adjusting the structure upgrading, every year A farmer associations and the province companies will jointly organized "Xinjiang Agricultural industry Expo", attracted nearly 2,000 kinds of agricultural products from outside the province 200 exhibitors Yu Jianong products business. For example, in 2014, A company held in Urumqi based Asia-Europe Cooperation Forum on International Agricultural Industry Agricultural Fair. This activity is also connected to move the province to carry $120 \mathrm{Yu}$ Jianong products business has been in technology, human resources, management and common progress, agricultural enterprises in the province to stimulate the huge potential for development. A For the enterprises themselves, they expected to achieve full self-supply gap fill-season agricultural products in 2016, hoping to export anti-quarter 2015 incremental to produce 230,000 tons 500,000 tons, make up nearly 300,000 tons of agricultural exports export, breaking trade restrictions on European Union, Russia and other areas of this plan, is also seen as the 
province of all a enterprises and agricultural enterprises a great opportunity in the future strategic development "One belt One road" of.

\section{Challenges of A Xinjiang agricultural product in marketing activities}

A Xinjiang agricultural product enterprise in the marketing process also faces challenges due to the new pattern of opening up and development of enterprises and the increasingly fierce competition in the industry under the New Deal caused, it also in the future A company with import and export marketing activities to a series of challenges.

The challenges of the financial crisis and the new economy brought about by the normal.

Although the US financial crisis over the past eight years, but it brings the global impact is profound, the level of consumption caused by the financial markets, it is low so far there are aftershocks. While the international community is also continuing to take measures to actively corrected, but still can not completely reversed in the short term. A company such as in the marketing of agricultural products import and export activities on deeply affected. From them after the 2008 financial crisis, trade volume straight down 45\%, the fourth consecutive year and exports of agricultural products unsalable phenomenon, affecting extremely serious. From after 2014, "One belt One road" strategy, officially opened the new Silk Road economic corridor, import and export of agricultural products marketing activities in Xinjiang have the recovery. From 2013 to 2015 three years, A company has gradually opened, including Kyrgyzstan, Kazakhstan and other countries of the five Central Asian Foreign Agricultural marketing and trade cooperation, as well as with the EU to establish a good relationship between import and export. Import and export trade volume between 3 years are rising, the rate of increase at $7.8 \%, 15.3 \%$ and $21.2 \%$. Thus, A business has entered a new normal together with the Xinjiang agricultural industry, industrial structure and mode of development, it has also updated. But at the same time, significant changes in the rhythm of economic growth but also for A enterprise has brought new challenges that can better adapt to the new normal, and seek economic structure smooth transition, this is A and the whole enterprise in Xinjiang agricultural enterprises in need to solve problems in the future.

\section{The challenges brought by new marketing mode selection.}

For A company under the guidance of the new strategy, innovation and development model of its agricultural products and services, or more diversified, A company will be called "diversity collaborative innovation cluster" that is guided by the government, the market decided that the enterprise leading diversified co - agglomeration innovative marketing model.

A company is a local leading agricultural enterprise, so their positive response to the Government's guidance, understanding the "One belt One road" the spirit of the strategy, so that the government guidance to promote innovation-based external innovation mode. In addition, A leading companies to do their own positive development and export marketing model innovation, such as technical exchanges with portable type, import and export of agricultural exchanges, positive exchanges between the business culture and technology rich marketing activities, etc., which are enhancing the overall their own marketing innovation model. But under the influence of the combined effect of diversification, A company in product marketing and import and export there are still relatively unstable, such as fruits and vegetables for export in Russia between 2014 and 2015 in nearly two years, $8.5 \%$ of the trade volume fluctuations, a further description of these companies failed to fully adapt to the new marketing model brought about changes in the market and therefore adapt to the new industrial clustering innovation, forming a virtuous relationship between the leading import and export enterprises for the future development of a is a great challenge [3] .

\section{Conclusions}

Under the new location and historical opportunity "One belt One road" strategy, Xinjiang agricultural trade enterprises in the marketing process will be challenged even setbacks are inevitable, the key lies in the province enterprises to actively respond to the call of the policy, to implement communication policy, China Unicom road unimpeded trade, monetary circulation and support of the 
people connected. Only by achieving everywhere the same, Xinjiang agricultural trade enterprises will have the incentive to innovate and develop more open space, perfect to adapt to future important historical role "New Silk Road core economic zone".

\section{References}

[1] Liu Linxiu. Opportunities and challenges faced by Xinjiang under One Belt One Road background, Economic forum,2015(4):41-43.

[2] Li Ming. International Management Strategy study of Xinjiang' s Tomato Processing Industry. Tianjin University,2006.11-18.

[3] Wang Ye. Research of Xinjiang Agricultural International Trade under open conditions. Chinese Academy of Agricultural Sciences, 2015.62-69. 